\title{
Pengaruh kopi arabika terhadap perubahan warna resin komposit hybrid
}

\author{
${ }^{1}$ Style V. Sirang \\ ${ }^{2}$ P. S. Anindita \\ ${ }^{2}$ Juliatri \\ ${ }^{1}$ Kandidat Skripsi Program Studi Pendidikan Dokter Gigi Fakultas Kedokteran \\ ${ }^{2}$ Program Studi Pendidikan Dokter Gigi Fakultas Kedokteran \\ Universitas Sam Ratulangi Manado \\ Email: styleverlian@icloud.com
}

\begin{abstract}
Composite resin is one of the restorations used in the field of dentistry due to its good esthetic property. To date, the most commonly used composite resin is the hybrid type. Its weakness is the nature of fluid absorbance that can change its color. This discoloration can caused inter alia by food and beverage consumption. Arabica coffee is mostly consumed by our society, however, it has deposit of chlorogenic acid that might cause discoloration. This study was aimed to assess the influence of arabica coffee to the discoloration of hybrid composite resins. This was a true experimental study with a pre test and post test only control group design. Total samples were 24 composite resins of hybrid type (diameter $5 \mathrm{~mm}$ and height $2 \mathrm{~mm}$ ). Each treatment group consisted of 6 samples. The samples were divided into 4 treatment groups, as follows: 0 day, 3 days, 5 days, and 7 days of immersion in arabica coffee solution. The one-way anova test showed that the influence of arabica coffee solution to discoloration of composite resins was significant $(p=0.00)$. Conclusion: There was a significant influence of the duration of immersion in arabica coffee to discoloration of hybrid composite resins
\end{abstract}

Keywords: resin composite, discoloration, arabica coffee

\begin{abstract}
Abstrak: Resin komposit merupakan salah satu bahan restorasi yang sering digunakan di bidang kedokteran gigi karena memiliki nilai estetik yang baik. Saat ini jenis resin komposit yang sering digunakan yaitu resin komposit tipe hybrid. Resin komposit memiliki kekurangan yaitu sifat absorbansi cairan yang dapat menyebabkan perubahan warna. Salah satu penyebab perubahan warna yaitu makanan dan minuman. Kopi arabika merupakan minuman yang sering dikonsumsi oleh masyarakat dan memiliki kandungan asam klorogenik yang dapat memengaruhi perubahan warna. Penelitian ini bertujuan untuk mengetahui pengaruh kopi arabika terhadap perubahan warna resin komposit hybrid. Jenis penelitian ialaj eksperimental murni dengan pre test dan post test only control group design. Jumlah sampel penelitian yaitu 24 resin komposit tipe hybrid dengan ukuran diameter $5 \mathrm{~mm}$ dan tinggi $2 \mathrm{~mm}$, dibagi dalam tiga kelompok. Masing-masing kelompok perlakuan terdiri dari 6 sampel. Sampel dibagi menjadi 4 kelompok yaitu kelompok perlakuan 0 hari, 3 hari, 5 hari, dan 7 hari perendaman dalam larutan kopi arabika. Hasil analisis data dengan uji one way Anova menunjukkan adanya pengaruh kopi arabika terhadap perubahan warna resin komposit $(\mathrm{p}=0,00)$. Simpulan: Terdapat pengaruh bermakna dari lama perendaman dalam kopi arabika terhadap perubahan warna resin komposit hybrid.
\end{abstract}

Kata kunci : resin komposit, perubahan warna, kopi arabika

Dewasa ini kesadaran masyarakat terhadap kesehatan gigi dan mulut semakin meningkat. Peningkatan kesadaran tersebut bukan hanya terhadap penyakit gigi dan 
mulut saja namun juga peningkatan kebutuhan estetik gigi dan mulut.

Untuk mendapatkan estetik yang baik terdapat beberapa cara yang biasa dilakukan seperti whitening dan bleaching, namun tindakan perbaikan estetik yang utama yaitu penumpatan. Penumpatan yang baik dan memiliki nilai estetik dapat dicapai antara lain dengan penggunaan bahan resin komposit, karena warnanya mirip dengan warna struktur gigi asli. ${ }^{1}$

Seiring berkembanganya teknologi, resin komposit telah mengalami beberapa perubahan. Saat ini jenis yang banyak digunakan yaitu resin komposit tipe hybrid. Meskipun nilai estetiknya baik, resin komposit ini memiliki kekurangan yaitu memiliki sifat absorbsi cairan sebesar 0,5$0,7 \mathrm{mg} / \mathrm{cm}^{2}$. Sifat ini menunjukkan tendensi untuk perubahan warna. ${ }^{2}$

Perubahan warna bahan restorasi resin komposit dapat disebabkan oleh faktorfaktor ekstrinsik, salah satunya makanan dan minuman. ${ }^{3}$ Beberapa hal yang bisa menyebabkan perubahan warna tumpatan resin komposit di dalam mulut antara lain kebersihan mulut yang rendah, pemakaian obat kumur, pengaruh nikotin dari rokok, serta pengaruh dari zat warna dalam minuman yang dikonsumsi sehari-hari. Kandungan asam dalam kopi menyebabkan terjadinya microleakage, sehingga zat warna pada kopi diserap oleh permukaan resin komposit dan menyebabkan perubahan warna. ${ }^{4}$

Kopi merupakan minuman yang sering dikonsumsi oleh masyarakat Indonesia. Minuman ini dikonsumsi rata-rata tiga kali sehari oleh masyarakat baik oleh pria, wanita, dewasa maupun lansia. Penelitian sebelumnya menunjukkan bahwa kopi robusta dapat menyebabkan perubahan warna resin komposit ${ }^{5}$ sedangkan kopi jenis lain yaitu arabika dengan derajat keasaman lebih rendah belum pernah diteliti. ${ }^{6}$ Tujuan penelitian ini ialah untuk mendapatkan pengaruh kopi arabika terhadap perubahan warna resin komposit hybrid.

\section{BAHAN DAN METODE PENELITIAN}

Jenis penelitian ini ialah eksperimental murni (true experimental design) dengan pre test and post test only control group design. Penelitian ini dilaksanakan di Laboratorium Analisis Farmasi Fakultas Matematika Ilmu Pengetahuan Alam dan di Program Studi Pendidikan Dokter Gigi Fakultas Kedokteran Universitas Sam Ratulangi pada bulan September 2016.

Cetakan sampel terbuat dari sedotan plastik dengan ukuran diameter $5 \mathrm{~mm}$ dan tinggi $2 \mathrm{~mm}$ yang diletakkan di atas glass $l a b$, kemudian resin komposit diaplikasikan kedalam cetakan dan dilakukan penyinaran selama 40 detik dengan jarak $1 \mathrm{~mm}$ sesuai dengan ketentuan penggunaan. Resin yang telah mengeras dilepas dari cetakan dengan menggunakan pinset dan sonde. Sampel yang dibuat untuk penelitian ini sebanyak 18 buah dan dikelompokkan sebanyak 6 buah untuk setiap kelompok perlakuan.

Pada penelitian ini kelompok kontrol dan kelompok perlakuan menggunakan larutan kopi yang sama. Pembuatan larutan kopi sebanyak 20 gram lalu di larutkan dengan $360 \mathrm{ml}$ air panas $\left(90-96^{\circ}\right)$, lalu larutan didiamkan selama 15 menit hingga sesuai dengan suhu ruangan. ${ }^{7}$ Larutan kopi yang sudah siap dibagi sebanyak $20 \mathrm{ml}$ untuk masing-masing 18 tabung kelompok perlakuan dan 1 tabung kelompok kontrol.

Pengukuran kopi yang dilakukan pada kelompok kontrol ini tidak direndam dengan sampel. Larutan kopi didiamkan selama 15 menit, selanjutnya dilakukan pengenceran larutan kopi dengan cara $1 \mathrm{ml}$ larutan kopi dilarutkan dengan aquades sebanyak $9 \mathrm{ml}$, diletakkan dalam alat colorflex EZ Spectrophotometer, dan hasil dicatat sebagai nilai perubahan warna 0 hari.

Sampel dibagi atas tiga kelompok, yaitu kelompok 1 selama tiga hari perendaman dalam larutan kopi arabika dengan resin komposit; kelompok 2 selama lima hari perendaman dalam larutan kopi arabika dengan resin komposit; dan kelompok 3 selama tujuh hari perendaman dalam larutan kopi arabika dengan resin komposit.

Tabung reaksi yang telah diisi dengan larutan kopi arabika sebanyak $10 \mathrm{ml}$ diberi label kertas yang berisi tanggal dan jam 
dimulai perendaman, lama perendaman, tanggal, jam selesai perendaman, dan didiamkan di dalam inkubator dengan suhu $37^{\circ} \mathrm{C}$. Selanjutnya pengukuran pada setiap kelompok sesuai lamanya hari perendaman, dengan cara melakukan pengenceran diambil masing-masing $1 \mathrm{ml}$ dari tiap larutan lalu diencerkan dengan aquades sebanyak $9 \mathrm{ml}$. Sampel yang sudah disiapkan diletakan di dalam alat colorflex EZ Spectrophotometer, dan dihubungkan dengan komputer lalu tekan start tunggu beberapa detik untuk proses pembacaan nilai dari sampel tersebut. Nilai yang keluar dicatat sebagai hasil perubahan warna.

\section{HASIL PENELITIAN}

Berdasarkan pengukuran yang telah dilakukan dapat dilihat perubahan warna yang terjadi pada resin komposit yang direndam kopi arabika sebelum dilakukan perlakuan dan dengan 3, 5, dan 7 hari sesudah perlakuan.

Berdasarkan Tabel 1 terlihat bahwa rerata nilai absorbansi larutan kopi arabika kelompok kontrol tidak berubah baik setelah 3, 5, maupun 7 hari perendaman sedangkan kelompok perlakuan menunjukkan nilai absorbansi yang meningkat.

Tabel 1. Hasil pengamatan absorbansi larutan kopi arabika yang direndam dengan resin komposit dan larutan kopi arabika tanpa resin komposit (RK)

\begin{tabular}{ccc}
\hline Lama & \multicolumn{2}{c}{ Nilai absorbansi } \\
\cline { 2 - 3 } perendaman & Kopi + RK & Kopi \\
\hline 0 hari & 0,181 & 0,178 \\
3 hari & 0,236 & 0,178 \\
5 hari & 0,264 & 0,178 \\
7 hari & 0,329 & 0,178 \\
\hline
\end{tabular}

Hasil perhitungan uji normalitas (Tabel 2) memperlihatkan kelompok kontrol memiliki nilai $\mathrm{p}<0,05$ yang menunjukkan data tidak terdistribusi secara normal, sehingga uji selanjutnya menggunakan uji Friedman (Tabel 3).

Uji Friedman digunakan bila data yang didapatkan tidak terdistribusi secara normal. Hasil yang diperoleh menunjukkan tidak terdapat perbedaan bermakna ( $\mathrm{p}=0,845)$, maka dapat disimpulkan bahwa kelompok kontrol tidak memiliki nilai absorbansi yang bermakna. Hal ini yang membuktikan bahwa kopi tanpa rendaman resin komposit memiliki nilai absorbansi yang sama pada berbagai hari rendaman.

Tabel 2. Uji normalitas Shapiro Wilk

\begin{tabular}{ccccc}
\hline \multirow{2}{*}{$\begin{array}{c}\text { Jenis } \\
\text { larutan }\end{array}$} & \multicolumn{4}{c}{ Shapiro Wilk } \\
\cline { 2 - 5 } & Hari & Rerata & df & Sig \\
\hline Resin & 0 & 0,900 & 6 & $0,372^{*}$ \\
komposit & 3 & 0,863 & 6 & $0,198^{*}$ \\
+ & 5 & 0,840 & 6 & $0,131^{*}$ \\
Kopi & 7 & 0,813 & 6 & $0,076^{*}$ \\
\hline \multirow{2}{*}{ Kopi } & 0 & 0,750 & 3 & 0,000 \\
& 3 & 0,750 & 3 & 0,000 \\
& 5 & 0,750 & 3 & 0,000 \\
& 7 & 0,750 & 3 & 0,000 \\
\hline
\end{tabular}

Tabel 3. Uji Friedman

\begin{tabular}{ccccc}
\hline $\begin{array}{c}\mathbf{N} \\
\text { (hari) }\end{array}$ & $\mathbf{N}$ & Chi-square & df & Sig \\
\hline 0 hari & 3 & & & \\
3 hari & 3 &, 818 & 3 &, 845 \\
5 hari & 3 & & & \\
7 hari & 3 & & & \\
\hline
\end{tabular}

Berbeda halnya dengan kelompok perlakuan yang mendapatkan nilai $\mathrm{p}>0,05$ yang menunjukkan data terdistribusi normal, sehingga uji selanjutnya menggunakan uji one way Anova (Tabel 4).

Pada Tabel 4 didapatkan hasil pengujian homogenitas pada kelompok perlakuan dengan nilai $p>0,05$ yang berarti sampel terdistribusi homogen. Uji ini bertujuan untuk mengetahui homogenitas data dan tiap kelompok memiliki varian yang sama. Selanjutnya dilakukan uji One Way Anova untuk mengetahui apakah terdapat perbedaan bermakna antara dua kelompok atau lebih.

Hasil uji One Way Anova menunjukkan nilai signifikansi 0,000 yang berarti bahwa terdapat pengaruh perendaman resin komposit dalam larutan kopi arabika dengan perbedaan hari terhadap perubahan warna resin komposit karena hasil yang didapat $\mathrm{p}<0,005$ (Tabel 5). 
Sirang, Anindita, Juliatri: Pengaruh kopi arabika terhadap perubahan ...

Tabel 4. Uji homogenitas menggunakan Levene Statistic

\begin{tabular}{ccccc}
\hline Jenis larutan & Levene Statistic & df1 & df2 & Sig. \\
\hline Resin komposit + Kopi & 2,962 & 3 & 20 & 0,057 \\
\hline
\end{tabular}

Tabel 5. Uji One Way Anova

\begin{tabular}{cccc}
\hline Jenis larutan & & $\begin{array}{c}\text { Sig } \\
\text { (post hoc) }\end{array}$ & Sig \\
\hline Resin komposit + & 3 dan 5 hari & 0,852 & \\
Kopi & 3 hari dan 7 hari & 0.033 &, $000^{*}$ \\
& 5 hari dan 7hari & 0,774 & \\
\hline
\end{tabular}

* $\mathrm{p}<0,005$ bermakna

\section{BAHASAN}

Hasil penelitian ini menunjukkan bahwa terdapat pengaruh perubahan warna resin komposit akibat perendaman kopi arabika selama 3, 5, dan 7 hari. Hal ini serupa dengan penelitian yang dilakukan oleh Maulida ${ }^{5}$ di Jember yang menunjukkan bahwa perubahan warna resin komposit terjadi setelah melakukan perendaman pada kopi jenis robusta. Kopi Arabika memiliki kandungan asam klorogenik yang cukup tinggi yaitu 5,5\% sampai $8 \%$, namun demikian kopi Robusta memiliki kandungan asam klorogenik yang lebih tinggi yaitu $7 \%$ sampai $10 \%$.

Pengaruh perubahan warna resin komposit akibat perendaman kopi arabika memiliki nilai yang terus meningkat, mulai dari 3, 5, dan 7 hari setelah perendaman. Hasil ini serupa dengan penelitian yang dilakukan oleh Khatimah et al. ${ }^{8}$ di Jakarta pada tahun 2012 yang menunjukkan semakin lama waktu perendaman resin komposit maka semakin besar perubahan warna yang akan terjadi.

Perubahan warna yang terjadi pada resin komposit dapat bervariasi, hal ini disebabkan oleh beberapa faktor, antara lain: ukuran sampel, mikroporositas sampel, dan lama kontak antar bahan. Semakin luas ukuran sampel maka kemungkinan kontak dengan bahan lain semakin besar sehingga perubahan fisik pada bahan dapat terjadi. Mikroporositas menentukan terjadinya penempelan partikel warna daerah yang porus. Zat warna yang terabsorbansi melalui proses difusi juga akan semakin banyak. Lama kontak antara resin komposit dan lama perendaman yang mengandung zat warna berbanding lurus dengan perubahan warna. ${ }^{9}$

Pada penelitian ini perubahan warna pada resin komposit dapat terjadi karena adanya zat asam klorogenik yang terkandung pada kopi arabika. Asam klorogenik yang terkandung di dalam kopi merupakan senyawa fenol propanoit. Seyawa ini memiliki kandungan yang cukup besar yaitu 5,5\% sampai 8\%.Jika senyawa ini berkontak dengan resin komposit maka menunjukan peningkatan berat dan pengaruh kimiawi yang sifatnya merusak permukaan resin. Fenol propanoit tersebut akan masuk ke dalam permukaan resin dan mengakibatkan permukaan mengembang dan menjadi lunak. ${ }^{6}$ Hal ini didukung pula dengan sifat dari resin komposit yang dapat menyerap air secara perlahan-lahan dalam jangka waktu tertentu dengan mekanisme penyerapan melalui difusi molekul air. Ekspansi higroskopis cairan dapat terjadi 15 menit setelah polimerisasi sampai mencapai titik jenuh pada hari ke-7. ${ }^{10}$ Penyerapan zat asam kloregenik ini ke dalam resin komposit akan diikuti oleh penyerapan substansi lain dari larutan kopi arabika, termasuk zat pewarna yang terkandung di dalamnya.

Hasil dari penelitian ini menunjukan bahwa terdapat pengaruh kopi arabika terhadap perubahan warna resin komposit. Hal ini mungkin disebabkan oleh asam 
klorogenik yang terkandung di dalam kopi arabika.

\section{SIMPULAN}

Terdapat pengaruh bermakna dari lama perendaman dalam kopi arabika terhadap perubahan warna resin komposit hybrid.

\section{SARAN}

1. Perlu dilakukan penelitian lanjutan dengan cara mengukur langsung pada resin komposit yang telah dilakukan perendaman.

2. Penelitian lanjutan pada pasien peminum kopi yang menggunakan bahan restorasi resin komposit.

\section{DAFTAR PUSTAKA}

1. Maulani C. Bahan tambal estetik direk dan indirek. Jurnal PDGI online. 2004. Available from www.pdgi-online.com.

2. Phillip RW. Science of Dental Materials (9th ed). Philadelphia. WB Sounders Co, 1991; p.157-216.

3. Craig RG, Powers JM. Restorative Dental Materials (11th ed). St Louis Missouri: Mosby Inc, 2002; p.232-47.

4. Megumi F, Kawakami S, Noda M, Hidehiko. Color stability of newly developed esthetic restorative material immersed in food simulating solution.
Dent Mater Journal. 2006;25(2):352-3.

5. Maulida SC. Pengaruh kebiasaan minum kopi robusta (coffea robusta) terhadap perubahan warna pada restorasi resin komposit nanofiller [Skripsi]. Jember: Fakultas Kedokteran Gigi Universitas Jember; 2014.

6. Rubiyo. Pengaruh lama fermentasi terhadap kadar keasaman kopi. Bali: Departemen Pertanian Pemprov Bali, 2005; p. 23. Available from: www.litbang.deptan.go.id.

7. Candra R. Alat suhu ruangan melalui web berbasiskan mikrokontroler AT89s51. Proceeding Seminar Ilmiah Nasional Komputer dan Sistem Intelijen (KOMMIT 2006). Depok: Universitas Gunadarma, 2006; p. 535.

8. Khatimah H, Aristiana B, Yuliana I, Agustiono P. Pengaruh lama perendaman larutan kunyit asam terhadap perubahan warna resin komposit hybrid. Insisiva Dental. 2012;1(2):69-73.

9. Philips AKJ. Science of Dental Materials (3rd ed). London: Mosby Elsevier, 2007; p. 401-46.

10. Turkun M. Color changes of three veneering composite resin after staining, bleaching and polishing procedure. Turki: Department of restorative dentistry and endodontics, 2003. Available from: www.iads.caylx.com. 